\title{
Stage of bladder cancer in Central Europe - Polish perspective
}

\author{
S. POLETAJEW ${ }^{1, *}$, R. BIERNACKI ${ }^{2}$, P. BURACZYNSKI ${ }^{3}$, J. CHOJNACKI ${ }^{4}$, S. CZARNIECKI ${ }^{5}$, D. GAJEWSKA ${ }^{6}$, T. POHABA ${ }^{7}$, J. SONDKA ${ }^{8}$, \\ M. SKRZYPCZYK ${ }^{4}$, T. SUCHOJAD ${ }^{9}$, D. WOJTKOWIAK ${ }^{10}$, B. ZAFOREMSKI ${ }^{11}$, L. ZAPALA ${ }^{12}$, A. ZEMLA ${ }^{13}$, P. RADZISZEWSKI ${ }^{1}$
}

${ }^{1}$ Department of Urology, Medical University of Warsaw, Warsaw, Poland; ${ }^{2}$ Department of Urology, The Regional Hospital, Leszno, Poland; ${ }^{3}$ Department of Urology, Medical University of Lublin, Lublin, Poland; ${ }^{4}$ Department of Urology, Center of Postgraduate Medical Education, Warsaw, Poland; ${ }^{5}$ Department of Urology, John Paul II Western Hospital, Grodzisk Mazowiecki, Poland; ${ }^{6}$ Department of Urology and Urological Oncology, Pomeranian Medical University, Szczecin, Poland; ${ }^{7}$ Department of Urology, The Regional Multidisciplinary Hospital, Jastrzębie Zdrój, Poland; ${ }^{8}$ First Department of Urology, Military Medical Academy University Teaching Hospital - Central Veterans Hospital, Łódź, Poland; ${ }^{9}$ Departament of Urology, Provincial Specialist Hospital, Czerwona Góra, Poland; ${ }^{10}$ Department of Urology, Regional Hospital Centrum, Jelenia Góra, Poland; ${ }^{11}$ Department of Urology and Oncological Urology, John Paul II Subcarpatian Provincial Hospital, Krosno, Poland; ${ }^{12}$ Department of Urology, Multidisciplinary Hospital Warsaw-Miedzylesie, Warsaw, Poland; ${ }^{13}$ Department of Urology and Urological Oncology, Lowersilesian Multidisciplinary Hospital, Wrocław, Poland

*Correspondence: slawomir.poletajew@wum.edu.pl

Received January 16, 2016 / Accepted April 25, 2016

\begin{abstract}
Mortality rate from bladder cancer in Europe is the highest in its Central Region. This study is an attempt to find underlying factors by proper characterisation of large cohort of Polish patients with bladder cancer.

This is a multicentre study enrolling 1360 consecutive patients diagnosed with primary urothelial carcinoma of the bladder in years 2012-2013 in Poland. All patients underwent transurethral resection of the bladder tumor. Data on staging and grading of all cancers were collected, as well as several demographic and clinical factors were tested for the association with muscle invasiveness of the cancer.

Mean age of the cohort was 69.6 years, male to female ratio was 3:1. Bladder cancer stage Ta, T1 and muscle-invasive (MIBC) was diagnosed in 533 (39.2\%), 516 (37.9\%) and 296 (21.8\%) patients, respectively. Patients with MIBC were older ( 73 vs. 68 years, $\mathrm{p}<0.05$ ), had lower body mass index ( $25.4 \mathrm{vs.} 26.5 \mathrm{~kg} / \mathrm{m} 2, \mathrm{p}<0.05)$, lower haemoglobin concentration (12.2 vs. $13.4 \mathrm{mg} / \mathrm{l}, \mathrm{p}<0.05)$, longer history of haematuria ( $86.2 \mathrm{vs} .74 .4$ days) and longer time interval from first symptom to diagnosis (118.0 vs. 88.2 days), compared to patients with Ta and T1 tumors.

High mortality rate from bladder cancer in Central Europe can result from very high incidence of high-risk T1 tumors and high prevalence of prognostic factors of poor survival.
\end{abstract}

Key words: bladder cancer, diagnosis, cancer stage, prognosis, Central Europe

Bladder cancer is the most common malignancy occurring within the urinary tract. According to GLOBOCAN data, the incidence in Central and Eastern Europe is 14.6 and 2.6 new cases per 100000 habitants per year among men and women, respectively [1]. Despite the progress in treatment protocols, mortality from bladder cancer in Poland, Romania and Bulgaria did not decline over last 15 years [2]. Simultaneously, the mortality rate from bladder cancer in Poland, Spain, Latvia and Lithuania are the highest in Europe, as reported by Bosetti et al. in European analysis [2]. The spectrum of the disease covers cases of non muscle-invasive bladder cancer (NMIBC) and muscle-invasive bladder cancer (MIBC). They differ in terms of biology, potential of progression, prognosis and treatment modes. Due to these facts, MIBC requires special attention among clinicians. Recently Dybowski et al. outlined relatively poor survival after radical cystectomy in Poland [3]. This leads to open discussion about factors that can be modified in order to improve treatment outcomes in Central Europe. Probably the first rational step in the process is proper characterisation of bladder cancer cases in the region. Unfortunately, detailed and reliable epidemiological data regarding Central Europe, including Poland are not available. While trends in incidence, potential exposure to risk factors of carcinogenesis in urothelium, lifestyle and health systems may vary between regions, the extrapolation of Western European data into Central Europe could be confusing. The aim of this study was to present 
oncological characteristics of large cohort of Polish patients with primary urothelial carcinoma of the bladder.

\section{Patients and methods}

Material. All patients with primary urothelial carcinoma of the bladder diagnosed in years 2012-2013 in 14 Polish urological centers participating in the project were retrospectively enrolled into the study. All patients underwent transurethral resection of the bladder tumor (TURBT). No exclusion criteria were adopted.

Methods. Data on staging and grading of all cancers were collected. Additionally several demographic and clinical factors were tested for the association with muscle invasiveness of the cancer. Microscopic examinations of TURBT specimens were performed by dedicated uropathologists. No central or local reviewing of pathological reports was done. For staging 2009 TNM classification was implemented. For grading 1973 WHO and / or 2004 WHO/ISUP classification was used depending on pathologist's personal experience and preference. For 1973 WHO classification no exact criteria of grading were established in this study, while for $2004 \mathrm{WHO}$ /ISUP classification the criteria proposed by International Society of Urological Pathology were respected.

Statistical analysis. Statistical calculations were done with Statistica 12.0 Software (StatSoft, USA). Results are presented as absolute values in case of parametric variables and mean or median values in case of non-parametric variables. Normal distribution was confirmed by the Shapiro-Wilk test, while the equality of variances was assessed using Levene's test. For comparison of quantitative variables between study subgroups (men vs. women or NMIBC patients vs. MIBC patients) unpaired t-test or U-Mann Whitney test were adopted. In case of qualitative variables, Chi2 test with McNemar formula was implemented. Differences were considered statistically significant when $\mathrm{p}$ value was $<0.05$.

\section{Results}

1360 patients were diagnosed with bladder cancer within the analysed time frame. Basic data on study population is presented in table 1.
Table 1. Basic characteristics of the study group

\begin{tabular}{lll}
\hline Number of patients & Total & 1360 \\
& Men & $75.4 \%(\mathrm{n}=1025)$ \\
& Women & $24.6 \%(\mathrm{n}=335)$ \\
\hline Age of patients (mean value) & Total & $69.6 \pm 11.3$ years \\
& Men & $69.6 \pm 11.1$ years \\
& Women & $69.8 \pm 11.9$ years \\
\hline History of cigarette smok- & Total & $57.0 \%(604 / 1059 \mathrm{pts})$ \\
ing * & Men & $60.2 \%(483 / 802 \mathrm{pts})$ \\
& Women & $47.1 \%(121 / 257 \mathrm{pts})$ \\
\hline History of haematuria ${ }^{*}$ & Total & $77.8 \%(1021 / 1312 \mathrm{pts})$ \\
& Men & $76.1 \%(245 / 322 \mathrm{pts})$ \\
& Women & $78.4 \%(776 / 990 \mathrm{pts})$ \\
\hline Time from first symptom to & Total & $30 \pm 181$ days (in $1012 \mathrm{pts})$ \\
TUR (median value) & Men & $30 \pm 173$ days (in $756 \mathrm{pts})$ \\
& Women & $30 \pm 204$ days (in $256 \mathrm{pts})$ \\
\hline
\end{tabular}

Results are presented as absolute or mean or median values or percentage. ${ }^{*}$ Reliable data was not available in all patients, given numbers present actual number of patients in whom appropriate information was collected.

Staging and grading of diagnosed cancers is presented in table 2. MIBC was diagnosed in $21.8 \%$ of cases. Patients with MIBC were significantly older and more frequently they reported incidences of haematuria comparing to patients with NMIBC. Advanced stage of the disease was associated with significantly lower BMI values and significantly lower haemoglobin concentrations. Also significantly longer time interval between first symptom and TUR was observed in MIBC group. Table 3 presents the comparison of patients diagnosed with NMIBC and MIBC.

\section{Discussion}

The data on European patients with bladder cancer come mainly from Western European countries. With latest papers presenting delay in radical cystectomy in over $20 \%$ of Central European patients and a 5-year survival following the surgery of $31.7 \%$ [3-5], one can think about differences in culture, lifestyle and health policy between the region of Central and Western Europe. As a consequence, we decided to perform

Table 2. Oncological characteristics of the study group

\begin{tabular}{lcccccccccc}
\hline T stage & Total number & Total $\%$ & G1 & G2 & G3 & $\begin{array}{c}1973 \text { WHO classification } \\
\text { used }\end{array}$ & PUNLMP & $\begin{array}{c}\text { LG } \\
\text { HG }\end{array}$ & $\begin{array}{c}2004 \text { WHO/ISUP } \\
\text { classification used }\end{array}$ \\
\hline a & 533 & $39.2 \%$ & 208 & 186 & 6 & $75.0 \%$ & 50 & 267 & 24 & $64.0 \%$ \\
1 & 516 & $37.9 \%$ & 89 & 246 & 60 & $76.6 \%$ & 13 & 191 & 143 & $67.2 \%$ \\
2 or higher & 296 & $21.8 \%$ & 2 & 76 & 155 & $78.7 \%$ & - & 15 & 168 & $61.8 \%$ \\
Cis alone & 2 & $0.1 \%$ & & & & & & & \\
x & 13 & $1.0 \%$ & 1 & 2 & 9 & $76.9 \%$ & - & 1 & 4 & $38.5 \%$ \\
Total & 1360 & $100 \%$ & 300 & 510 & 230 & $76.5 \%$ & 63 & 474 & 339 & $64.4 \%$ \\
\hline
\end{tabular}

Ta - Non-invasive papillary carcinoma; T1 - Tumor invades subepithelial connective tissue; T2 - Tumor invades muscle; Cis - carcinoma in situ, 'flat tumor'; x - Primary tumor cannot be assessed; G1-3 - grade 1-3; WHO - World Health Organisation grading classification; PUNLMP - papaillaryurothelial neoplasm of low malignant potential; LG - low grade cancer, HG - high grade cancer; ISUP - International Society of Urological Pathology grading classification 
Table 3. Comparison of patients diagnosed with NMIBC and MIBC

\begin{tabular}{lcc}
\hline Parameter & NMIBC & MIBC \\
\hline Number of patients & 1051 & 296 \\
Median age & $68 \pm 11.6 \mathrm{yrs}$ & $73 \pm 9.9 \mathrm{yrs}$ \\
Percentage of women & $24.7 \%(\mathrm{n}=260)$ & $24.0 \%(\mathrm{n}=71)$ \\
Height & $170.2 \pm 7.8 \mathrm{~cm}$ & $170.2 \pm 7.9 \mathrm{~cm}$ \\
BMI & $26.5 \pm 4.2 \mathrm{~kg} / \mathrm{m} 2$ & $25.4 \pm 4.0 \mathrm{~kg} / \mathrm{m} 2$ \\
Haemoglobin serum concentration & $13.4 \pm 2.0 \mathrm{mg} / \mathrm{l}$ & $12.2 \pm 2.4 \mathrm{mg} / 1$ \\
History of heamaturia & $74.4 \%(\mathrm{n}=760 / 1022)$ & $86.2 \%(\mathrm{n}=250 / 290)$ \\
History of nicotinism & $55.4 \%(\mathrm{n}=456 / 824)$ & 0.000 \\
Mean time from first symptom to TUR & $88.2 \pm 182.5$ days & 0.000 \\
\hline
\end{tabular}

a study aimed at basic clinical characterisation of Polish patients diagnosed with bladder cancer with the special focus on oncological data.

The main finding of our study is that the stage of primary bladder cancer in Poland differs from literature data. As the incidence of MIBC is similar to European data, the percentage of T1 tumors in the group of NMIBC patients is very high (table 2). The incidence of T1 tumors among patients with primary NMIBC in large contemporary international series is reported to be $36.8-39.0 \%[6,7]$. In our study, in the group of 1049 NMIBC cases, T1 tumors are noticed in $49.2 \%$ and hence these patients are qualified as high-risk patients based only on this sole criterion [8]. While the vast majority of these cases are also high-grade tumors, based on EORTC tables we can calculate the 5-year risk of progression of $17 \%$ [9]. What is more, according to European Association of Urology guidelines all these patients should be submitted to restaging TURBT with the risk of upstaging to MIBC of $4-25 \%$ [8]. These numbers may be even higher, as Fritsche et al. noticed the presence of MIBC after radical cystectomy in $49.7 \%$ of 1136 patients submitted to surgery due to T1 tumors [10].

In our cohort low grade or G1 and G2 tumors are most commonly observed. G3 and high-grade cancers consist 8.3\% and $24.3 \%$ of NMIBC cases, respectively (table 2). In the series of 1400 patients published by van der Meijden the G3 tumors were diagnosed in $11.9 \%$ of patients, however, agreement of local and review pathologist on grade in G3 tumors was observed only in $61.3 \%$ [11]. In more recent analysis considering 2004 WHO/ISUP classification and covering 327 patients, Schned et al. diagnosed high-grade tumors in $22.6 \%$ of cases with the agreement rate between pathologists of $83 \%$ [12]. The problem of discrepancies between pathologists opinion on tumor grade is both well known and unsolved, recently confirmed also in representative cohort of Polish population [13]. Simultaneously, the differences between the incidence of G3 and high-grade tumors outlines the core differences between 1973 WHO and 2004 WHO/ISUP classifications. May et al. found that high-grade tumors are diagnosed even five times more frequently than G3 tumors [14]. Due to this fact, we assessed also the preferences of pathologists in selecting the grading classification. While 1973 WHO classification is more popular than $2004 \mathrm{WHO} / \mathrm{ISUP}$ one, in the majority of cases grading is presented according to both classifications (table 2). As the evidence of the better prognostic value of 2004 WHO/ISUP classification is still lacking, only $51 \%$ pathologists use it in clinical practice [15], while European Association of Urology experts advise to use both $1973 \mathrm{WHO}$ and $2004 \mathrm{WHO}$ /ISUP classifications [8].

In present study the overall incidence of tobacco use is $57 \%$, significantly lower among women than among men (table 1). Two facts are worth mentioning at this point. First, the cigarette-related risk of bladder cancer development seems to have increasing trend in last years and this phenomenon can be explained by the decrease in nicotine concentration associated with the increase in carcinogens concentration in cigarettes [16]. Nowadays, the risk of bladder cancer is 2.0 to 2.6-fold higher in former smokers and 3.8 to 5.5 -fold higher in current smokers, when compared to never smokers [1719]. Second, some authors outline particularly increased risk of bladder cancer development in female smokers. Freedman et al. reported 4.7-fold and 3.9-fold higher risk in female and male current smokers, respectively [17].

In our cohort MIBC is diagnosed in significantly older patients than NMIBC. Prout et al. first highlighted that 75-year old and older patients with MIBC are less likely to undergo radical cystectomy when compared to younger patients, independently of physical status [20]. However, the general patient condition, including nutrition status and comorbidities seem to be more important prognostic factors than age alone [2123]. Simultaneously, data on the influence of age on survival after radical cystectomy are not consistent [24-29], although there is no doubt that the risk of severe surgical complications increases with patient age $[24,30,31]$. On the other hand, renal function and performance status diminish with increasing age and progression of oncological disease, what reduces the chance of qualification for cisplatin-based chemotherapy in advanced or metastatic disease.

Additionally, we observe longer time interval between the first symptom (mainly haematuria) and TUR in MIBC versus NMIBC patients. There is no data on the influence of TUR timing on treatment outcomes. However, one can assume, that 
delay in TUR lead to delay in radical cystectomy in patients with operable MIBC and fit for surgery. As a consequence, shorter survival can be expected [32-36].

We also report lower haemoglobin concentration and lower body mass index (BMI) in MIBC versus NMIBC group. Both facts can be associated with increased cancer-related catabolism. In bladder cancer patients low haemoglobin concentration can be attributed to anaemia of chronic disease, commonly seen in malignancy, as well as it can result from macro- or microhaematuria. Two recent research groups have independently reported that low haemoglobin concentration (defined as lower than 10.5 or $12.6 \mathrm{~g} / \mathrm{dL}$ ) is associated with shorter survival after radical cystectomy, especially in patients aged over 75 years $[24,37]$. The impact of BMI on the risk of carcinogenesis in bladder is controversial. Population studies present conflicting results $[38,39]$. It is well known that abnormal (low or high) BMI increases the risk of surgical complications of radical cystectomy [30, 40-42]. However, previously published studies on the obesity did not find any association between high BMI and survival after radical cystectomy, nor increased costs $[40,43,44]$. On the other hand, the malnutrition, which can be indirectly assessed also by low BMI, significantly decreases the survival after radical cystectomy [45].

Our study is not free of limitations. The most important is a bias related to the retrospective nature of the study. Second, slides were not re-assessed, so the staging and grading was based on subjective opinion of experienced but single pathologist. The risk of misdiagnosis is then considerable as discussed before. Finally, while the study presents representative population, it is not a national database. Every year over 6500 cases of bladder cancer are reported to Polish National Cancer Registry [46]. However, this number covers primary, as well as recurrent tumors, while the exact number of new cases is unfortunately not known.

\section{Conclusions}

Basic demographic data of Polish patients with primary bladder cancer does not differ from Western European population. Also the NMIBC to MIBC rate is comparable. However, the incidence of high-risk NMIBC is significantly higher. Additionally, in the group of MIBC several prognostic factors of poor survival are present at the time of initial diagnosis in substantial portion of patients. These facts can independently and directly lead to worse treatment outcomes in the region of Central Europe.

\section{References}

[1] FERLAY J, SHIN HR, BRAY F, FORMAN D, MATHERS C, et al. Estimates of worldwide burden of cancer in 2008: GLOBOCAN 2008. International journal of cancer Journal international du cancer. 2010; 127: 2893-917. http://dx.doi. org/10.1002/ijc.25516
[2] BOSETTI C, BERTUCCIO P, CHATENOUD L, NEGRI E, LA VECCHIA C, et al. Trends in mortality from urologic cancers in Europe, 1970-2008. European urology. 2011; 60: 1-15. http://dx.doi.org/10.1016/j.eururo.2011.03.047

[3] DYBOWSKI B, OSSOLINSKI K, OSSOLINSKA A, PELLER $\mathrm{M}$, BRES-NIEWADA E, et al. Impact of stage and comorbidities on five-year survival after radical cystectomy in Poland: single centre experience. Central European journal of urology. 2015; 68: 278-83. http://dx.doi.org/10.5173/ ceju. 2015.620

[4] POLETAJEW S, BRATICEVICI B, BRISUDA A, CAUNI $\mathrm{V}$, GRYGORENKO V, et al. Timing of radical cystectomy in Central Europe - multicenter study on factors influencing the time from diagnosis to radical treatment of bladder cancer patients. Central European journal of urology. 2015; 68: 9-14. http://dx.doi.org/10.5173/ceju.2014.444

[5] POLETAJEW S, LISINSKI J, MOSKAL K, ORNAT J, RENK $\mathrm{K}$, et al. The time from diagnosis of bladder cancer to radical cystectomy in Polish urological centres - results of CysTiming Poland study. Central European journal of urology. 2014; 67: 329-32. http://dx.doi.org/10.5173/ceju.2014.04.art2

[6] VEDDER MM, MARQUEZ M, DE BEKKER-GROB EW, CALLE ML, DYRSKJOT L, et al. Risk prediction scores for recurrence and progression of non-muscle invasive bladder cancer: an international validation in primary tumours. PloS one. 2014; 9: e96849. http://dx.doi.org/10.1371/journal. pone.0096849

[7] RINK M, FURBERG H, ZABOR EC, XYLINAS E, BABJUK $\mathrm{M}$, et al. Impact of smoking and smoking cessation on oncologic outcomes in primary non-muscle-invasive bladder cancer. European urology. 2013; 63: 724-32. http://dx.doi. org/10.1016/j.eururo.2012.08.025

[8] BABJUK M, BURGER M, ZIGEUNER R, SHARIAT SF, VAN RHIJN BW, et al. EAU guidelines on non-muscle-invasive urothelial carcinoma of the bladder: update 2013. European urology. 2013; 64: 639-53. http://dx.doi.org/10.1016/j. eururo.2013.06.003

[9] SYLVESTER RJ, VAN DER MEIJDEN AP, OOSTERLINCK W, WITJES JA, BOUFFIOUX C, et al. Predicting recurrence and progression in individual patients with stage $\mathrm{Ta}$ T1 bladder cancer using EORTC risk tables: a combined analysis of 2596 patients from seven EORTC trials. European urology. 2006; 49: 466-5. http://dx.doi.org/10.1016/j. eururo.2005.12.031

[10] FRITSCHE HM, BURGER M, SVATEK RS, JELDRES C, KARAKIEWICZ PI, et al. Characteristics and outcomes of patients with clinical T1 grade 3 urothelial carcinoma treated with radical cystectomy: results from an international cohort. European urology. 2010; 57(2): 300-9. http://dx.doi. org/10.1016/j.eururo.2009.09.024

[11] VAN DER MEIJDEN A, SYLVESTER R, COLLETTE L, BONO A, TEN KATE F. The role and impact of pathology review on stage and grade assessment of stages Ta and T1 bladder tumors: a combined analysis of 5 European Organization for Research and Treatment of Cancer Trials. The Journal of urology. 2000; 164: 1533-7. http://dx.doi.org/10.1016/S00225347(05)67022-X 
[12] SCHNED AR, ANDREW AS, MARSIT CJ, KELSEY KT, ZENS MS, et al. Histological classification and stage of newly diagnosed bladder cancer in a population-based study from the Northeastern United States. Scandinavian journal of urology and nephrology. 2008; 42: 237-42. http://dx.doi. org/10.1080/00365590801948166

[13] POLETAJEW S, FUS L, WALEDZIAK M, POMADA P, CIECHANSKA J, et al. Comparison of pathological staging and grading of urothelial bladder carcinoma in post-transurethral resection and post-radical cystectomy specimens. Polish journal of pathology : official journal of the Polish Society of Pathologists. 2014; 65: 305-12. http://dx.doi.org/10.5114/ pjp. 2014.48192

[14] MAY M, BROOKMAN-AMISSAH S, ROIGAS J, HARTMANN A, STORKEL S, et al. Prognostic accuracy of individual uropathologists in noninvasive urinary bladder carcinoma: a multicentre study comparing the 1973 and 2004 World Health Organisation classifications. European urology. 2010; 57: 850-8. http://dx.doi.org/10.1016/j. eururo.2009.03.052

[15] LOPEZ-BELTRAN A, ALGABA F, BERNEY DM, BOCCON-GIBOD L, CAMPARO P, et al. Handling and reporting of transurethral resection specimens of the bladder in Europe: a web-based survey by the European Network of Uropathology (ENUP). Histopathology. 2011; 58: 579-85. http://dx.doi. org/10.1111/j.1365-2559.2011.03784.X

[16] HOFFMANN D, HOFFMANN I, EL-BAYOUMY K. The less harmful cigarette: a controversial issue. a tribute to Ernst L. Wynder. Chemical research in toxicology. 2001; 14: 767-90. http://dx.doi.org/10.1021/tx000260u

[17] FREEDMAN ND, SILVERMAN DT, HOLLENBECK AR, SCHATZKIN A, ABNET CC. Association between smoking and risk of bladder cancer among men and women. Jama. 2011; 306: 737-45. http://dx.doi.org/10.1001/jama.2011.1142

[18] BARIS D, KARAGAS MR, VERRILL C, JOHNSON A, ANDREW AS, et al. A case-control study of smoking and bladder cancer risk: emergent patterns over time. Journal of the National Cancer Institute. 2009; 101: 1553-61. http:// dx.doi.org/10.1093/jnci/djp361

[19] WELTY CJ, WRIGHT JL, HOTALING JM, BHATTI P, PORTER MP, et al. Persistence of urothelial carcinoma of the bladder risk among former smokers: results from a contemporary, prospective cohort study. Urologic oncology. 2014; 32: 25. http://dx.doi.org/10.1016/j.urolonc.2012.09.001

[20] PROUT GR, JR., Wesley MN, Yancik R, Ries LA, Havlik RJ, et al. Age and comorbidity impact surgical therapy in older bladder carcinoma patients: a population-based study. Cancer. 2005; 104: 1638-47. http://dx.doi.org/10.1002/cncr.21354

[21] DJALADAT H, BRUINS HM, MIRANDA G, CAI J, SKINNER EC, et al. The association of preoperative serum albumin level and American Society of Anesthesiologists (ASA) score on early complications and survival of patients undergoing radical cystectomy for urothelial bladder cancer. BJU international. 2014; 113: 887-93. http://dx.doi.org/10.1111/ bju. 12240

[22] BOORJIAN SA, KIM SP, TOLLEFSON MK, CARRASCO A, CHEVILLE JC, et al. Comparative performance of co- morbidity indices for estimating perioperative and 5-year all cause mortality following radical cystectomy for bladder cancer. The Journal of urology. 2013; 190: 55-60. http://dx.doi. org/10.1016/j.juro.2013.01.010

[23] FAIREY A, CHETNER M, METCALFE J, MOORE R, TODD $\mathrm{G}$, et al. Associations among age, comorbidity and clinical outcomes after radical cystectomy: results from the Alberta Urology Institute radical cystectomy database. The Journal of urology. 2008; 180: 128-34. http://dx.doi.org/10.1016/j. juro.2008.03.057

[24] HARA T, MATSUYAMA H, KAMIRYO Y, HAYASHIDA S, YAMAMOTO N, et al. Use of preoperative performance status and hemoglobin concentration to predict overall survival for patients aged $>/=75$ years after radical cystectomy for treatment of bladder cancer. International journal of clinical oncology. 2015.

[25] NOVOTNY V, HAKENBERG OW, FROEHNER M, ZASTROW S, LEIKE S, et al. Systematic assessment of complications and outcome of radical cystectomy undertaken with curative intent in patients with comorbidity and over 75 years of age. Urologia internationalis. 2013; 90: 195-201. http://dx.doi. org/10.1159/000345790

[26] HOROVITZ D, TURKER P, BOSTROM PJ, MIRTTI T, NURMI M, et al. Does patient age affect survival after radical cystectomy? BJU international. 2012; 110(11 Pt B): E486-93. http://dx.doi.org/10.1111/j.1464-410X.2012.11180.x

[27] NIELSEN ME, SHARIAT SF, KARAKIEWICZ PI, LOTAN Y, ROGERS CG, ET AL. Advanced age is associated with poorer bladder cancer-specific survival in patients treated with radical cystectomy. European urology. 2007; 51: 699-706. http:// dx.doi.org/10.1016/j.eururo.2006.11.004

[28] FAIREY AS, KASSOUF W, APRIKIAN AG, CHIN JL, IZAWA JI, et al. Age $>/=80$ years is independently associated with survival outcomes after radical cystectomy: results from the Canadian Bladder Cancer Network Database. Urologic oncology. 2012; 30: 825-32. http://dx.doi.org/10.1016/j. urolonc.2011.07.014

[29] CHROMECKI TF, MAUERMANN J, CHA EK, SVATEK RS, FAJKOVIC $\mathrm{H}$, et al. Multicenter validation of the prognostic value of patient age in patients treated with radical cystectomy. World journal of urology. 2012; 30: 753-9. http://dx.doi. org/10.1007/s00345-011-0772-2

[30] SVATEK RS, FISHER MB, WILLIAMS MB, MATIN SF, KAMAT AM, et al. Age and body mass index are independent risk factors for the development of postoperative paralytic ileus after radical cystectomy. Urology. 2010; 76: 1419-24. http://dx.doi.org/10.1016/j.urology.2010.02.053

[31] NOVOTNY V, ZASTROW S, KOCH R, WIRTH MP. Radical cystectomy in patients over 70 years of age: impact of comorbidity on perioperative morbidity and mortality. World journal of urology. 2012; 30: 769-76. http://dx.doi. org/10.1007/s00345-011-0782-0

[32] GORE JL, LAI J, SETODJI CM, LITWIN MS, SAIGAL CS, UROLOGIC DISEASES IN AMERICA P. Mortality increases when radical cystectomy is delayed more than 12 weeks: results from a Surveillance, Epidemiology, and End ResultsMedicare analysis. Cancer. 2009; 115: 988-96. http://dx.doi. org/10.1002/cncr.24052 
[33] HARA I, MIYAKE H, HARA S, GOTOH A, OKADA H, et al. Optimal timing of radical cystectomy for patients with invasive transitional cell carcinoma of the bladder. Japanese journal of clinical oncology. 2002; 32: 14-8. http://dx.doi. org/10.1093/jico/hyf002

[34] LEE CT, MADII R, DAIGNAULT S, DUNN RL, ZHANG Y, et al. Cystectomy delay more than 3 months from initial bladder cancer diagnosis results in decreased disease specific and overall survival. The Journal of urology. 2006; 175: 1262-7. http://dx.doi.org/10.1016/S0022-5347(05)00644-0

[35] MAY M, NITZKE T, HELKE C, VOGLER H, HOSCHKE $B$. Significance of the time period between diagnosis of muscle invasion and radical cystectomy with regard to the prognosis of transitional cell carcinoma of the urothelium in the bladder. Scandinavian journal of urology and nephrology. 2004; 38: 231-5. http://dx.doi. org/10.1080/00365590410029141

[36] SANCHEZ-ORTIZ RF, HUANG WC, MICK R, VAN ARSDALEN KN, WEIN AJ, et al. An interval longer than 12 weeks between the diagnosis of muscle invasion and cystectomy is associated with worse outcome in bladder carcinoma. The Journal of urology. 2003; 169: 110-5. http://dx.doi. org/10.1016/S0022-5347(05)64047-5

[37] SEJIMA T, MORIZANE S, YAO A, ISOYAMA T, SAITO $\mathrm{M}$, et al. Prognostic impact of preoperative hematological disorders and a risk stratification model in bladder cancer patients treated with radical cystectomy. International journal of urology : official journal of the Japanese Urological Association. 2014; 21: 52-7. http://dx.doi.org/10.1111/iju.12161

[38] KOEBNICK C, MICHAUD D, MOORE SC, PARK Y, HOLLENBECK A, et al. Body mass index, physical activity, and bladder cancer in a large prospective study. Cancer epidemiology, biomarkers \& prevention : a publication of the American Association for Cancer Research, cosponsored by the American Society of Preventive Oncology. 2008; 17: 1214-21. http:// dx.doi.org/10.1158/1055-9965.EPI-08-0026
[39] HOLICK CN, GIOVANNUCCI EL, STAMPFER MJ, MICHAUD DS. Prospective study of body mass index, height, physical activity and incidence of bladder cancer in US men and women. International journal of cancer Journal international du cancer. 2007; 120: 140-6. http://dx.doi.org/10.1002/ ijc. 22142

[40] BAGRODIA A, GROVER S, SRIVASTAVA A, GUPTA A, BOLENZ C, et al. Impact of body mass index on clinical and cost outcomes after radical cystectomy. BJU international. 2009; 104: 326-30. http://dx.doi.org/10.1111/j.1464-410X.2009.08358.x

[41] LEE CT, DUNN RL, CHEN BT, JOSHI DP, SHEFFIELD $\mathrm{J}$, et al. Impact of body mass index on radical cystectomy. The Journal of urology. 2004; 172: 1281-5. http://dx.doi. org/10.1097/01.ju.0000138785.48347.aa

[42] TERRY WJ, BUESCHEN AJ. Complications of radical cystectomy and correlation with nutritional assessment. Urology. 1986; 27: 229-32. http://dx.doi.org/10.1016/00904295(86)90279-7

[43] MAURER T, MAURER J, RETZ M, PAUL R, ZANTL N, et al. Influence of body mass index on operability, morbidity and disease outcome following radical cystectomy. Urologia internationalis. 2009; 82: 432-9. http://dx.doi. org/10.1159/000218533

[44] HAFRON J, MITRA N, DALBAGNI G, BOCHNER B, HERR $\mathrm{H}$, et al. Does body mass index affect survival of patients undergoing radical or partial cystectomy for bladder cancer? The Journal of urology. 2005; 173: 1513-7. http://dx.doi. org/10.1097/01.ju.0000154352.54965.14

[45] GREGG JR, COOKSON MS, PHILliPS S, SALEM S, CHANG SS, et al. Effect of preoperative nutritional deficiency on mortality after radical cystectomy for bladder cancer. The Journal of urology. 2011; 185: 90-6. http://dx.doi. org/10.1016/j.juro.2010.09.021

[46] WOJCIECHOWSKA U, DIDKOWSKA J, ZATONSKI W. Cancer in Poland in 2012. Warszawa: Polish National Cancer Registry; 2014. 